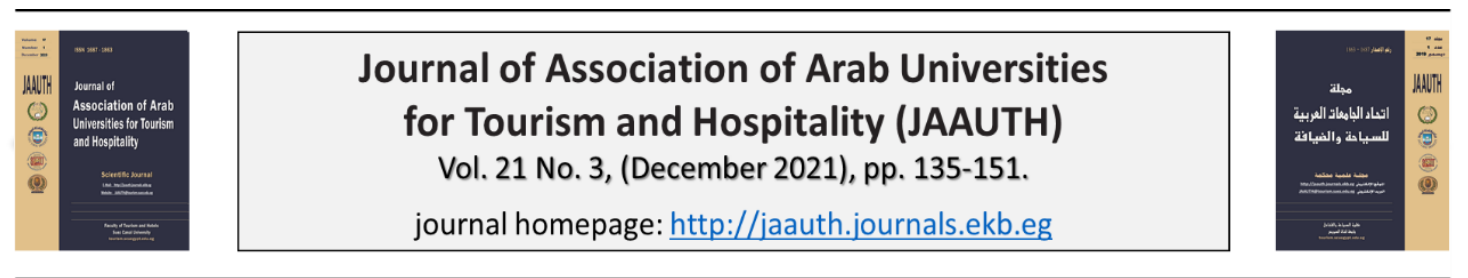

\title{
The Procedures of Planning Food Menus Between Knowledge and Actual Practice in the Egyptian Resorts
}

\author{
Mostafa Attia Abd El-Fattah \\ Faculty of Tourism and Hotel Management Beni-Suef University
}

\section{ARTICLE INFO \\ Keywords: \\ Food menu; Menu planning; Guest satisfaction; Type of menus; Food service.}

\section{(JAAUTH) \\ Vol. 21, No. 3, (December 2021), PP.135-151.}

\begin{abstract}
Food menu is one of the biggest influences on food service operations development of loyal guest's base and a positive return on its investment of energy, money, time and other resources. While, the food menu should meet or exceed guests' expectations, because guest satisfaction is the overall goal of food service management, the menu should, above all else, reflect the tastes and preferences of the guests not those of the executive chef, the food and beverage director, or the general manager. Therefore, menu planning is a complex process, but it can be successful when the focus, first and foremost is on the needs and expectations of guests. This study aims to measure the awareness and knowledge of who are responsible for planning the food menus in the Egyptian resorts of the study samples regarding to the food menu procedures and the actual application of these procedures in order to reach the best recommendations and suggestions that can contribute to the improvement of working in the Egyptian resorts. In order to achieve this aim, two sources of evidence were used. Faceto-face semi-structured interviews were conducted with the responsible for planning food menus in the Egyptian resorts to identify the extent of their awareness and knowledge regarding the food menu procedures that are actually applied. On the other hand, personal observation checklist was used to ensure that procedures are correctly applied. Moreover, the results also recommended that increase the awareness and skills of the responsible for planning food menus through support training programs.
\end{abstract}

\section{INTRODUCTION}

The first recorded menus data back to antiquity and have changed continuously throughout history. Originally, records of food served at banquets or festive occasions in ancient civilizations were closer to lists used in the preparation of food rather than menus and they were not given to diners. In the $18^{\text {th }}$ and $19^{\text {th }}$ centuries, menus began to appear in the windows of bistros and eateries in Europe (Graham, Michel, and David, 2012). 
On the other hand, The Egyptian Tourism Federation and AH\&LA* (2019) * stated there is a famous saying that in food and beverage service establishments "everything in restaurants starts with the menu". The menu dictates much about how your operation will be organized and managed, the extent to which it meets its goals, and even how the building itself should be designed and constructed.

The main job of food and beverage menu is to inform the patrons of the food that's available and the price for each item. It also informs the staff of foods that need to be produced (Davis, and Rensburg, 2008; and Corcoran, and Bloomquist, 2001). Meanwhile, Cichy (2004) declared that the study for planning food menus is not an easy matter, though there are a number of people believe that the food and beverage menu is only a mere list compilation of varieties of food and beverage items. While it's otherwise quote it is a matter of taste, artistic and scientific issue is made up of many of the specific, harmonious procedures and rules.

On the other hand, Miller, Dopson, and Hayes (2006) stated that the food menu is a list of food items served by any food service establishments. In more clearly terms, food menus are statements of the food and beverage items provided by a food service establishment, primarily based on guest needs and/or demands and designed to achieve food and beverage service establishment objectives. Also, Liza, and Lientjie (2008) added that the food menu is a production plan governing almost every step of the food and beverage service establishments and becomes the backbone of a food service establishments. Lenore Publication (2020) agreed with Anupam (2006) when stated that the menu planning means devising meals that are nutritionally adequate and acceptable to the patrons. Menu planning is really means that you plan ahead of time what meals will be cook (Peter, Michael, and Stephen, 2013).

The menu as a sales tool is not only important in any food and beverage establishments but is particularly so in these types of operations where staffing levels are reduced to a minimum and the operation's only vehicle for selling its products is via its menu and visual displays (Foskett, Ceserani, and Kinton, 2008 and Bernard, Andrew, Ioannis, and Peter, 2012). The menu is a powerful marketing tool that influences how food service establishment guest's will make purchasing decisions. The food menu marketing involves understanding the customer; grabbing the customer's attention; directing or influencing purchase decisions; and delivering expectations and using feedback to improve product, sales, profit contribution and customer satisfaction (Lendal, and Diane, 2008 and The Egyptian Tourism Federation and AH\&LA, 2019).

\section{LITERATURE REVIEW}

\section{1) Importance of menu planning:}

Planning the food menus is very important and necessary, where the executive chef must be sure to study the market, competitors and potential customers. Also, should be aware of a number of points, such as: raw materials, suppliers, equipment and tools,

* In Arabic 
* AH\&LA (American Hotel and Lodging Association)

storage spaces, kitchen employee's ... etc. (Barbara, and Sandi, 2005). Meanwhile, Cathie (2010) added that menu planning begins with building a foundation of knowledge and eliminating barriers to accessing healthy food choices and background influences. On the other hand, Al-Juboori, and Al Saleem, (2012) and Oxenreider, (2013) highlighted that understanding the concepts of menu is essential to building a successful restaurant, because the menu is the foundation upon which any food service organization builds its reputation and profit and, in effect, is show the restaurant first presents itself to customers (The Egyptian Tourism Federation and AH\&LA, 2010). A good menu should lead patrons to food selections that satisfy both their dining preferences and the merchandising priorities of the proprietor. It can also inform patrons of the hours of operation of special services available, and may even include information on the history of the establishment and its locale (Liza, and Lientjie, 2008).

The main purpose of menu planning is saves hours of time, energy, money and headaches, but it's easy to overcomplicate the process. And when that happens, it becomes a burden instead of a blessing (Peter, Michael, and Stephen, 2013). While, Divine (2013) declared that menu planning is the time consuming but very important finished product should fulfill the need of the test and give the people what they want, when they want. As explained by Brakes, (2013) once dishes are planned, costs per dish and selling prices need to be calculated. To do this, a large number of factors need to be considered, including portion cost of each food item, cost of condiments and other costs such as waste (Cichy, 2004).

\section{2) Factors affecting menu planning}

The menu is an important component of food service operations. It serves as a marketing tool, determines inventory, storage space required, skill level and number of cooking staff and service, equipment levels and types. Care should be taken when the menu is developed and modified to make sure the operation can handle the new additions to the menu (Qamiha, 2020* and Spears, and Gregoire, 2004). Moreover, Barker, Cavaliere, Fitzpatrick, Leaver, Mayerson, Rosen, Thompson, and Whittington, (2013) agreed with Al-Juboori, and Al Saleem, (2012) that menus should be planning to offer variety and choice to all guests, and are adapted to meet each guest's individual documented nutrition care needs and individual preferences. There are some factors affecting menu planning such as capital cost, budget, and labor consideration, availability of qualified labor, facility considerations, district availability and condition of equipment (Sprenger, 2015; and Divine, 2013).

There are many factors that affect the menu design; in addition, there are unique features of food service operational that need to be considered when planning menu design (The Egyptian Tourism Federation and AH\&LA, 2019) and (The Egyptian Tourism Federation and AH\&LA, 2010*). On the other hand, Kohinoor, (2010), and Spears, and Gregoire, (2004) highlighted that there are internal factors: (Consumer demands; Economic Condition; Competition; Supply levels and Industry trends) and external factors: (Facility's meal pattern; Concept and theme; Operational System, and 
Menu Mix) that leading to changing the menu. Meanwhile, Davis, and Rensburg, (2008) mentioned that the menu serves a variety of functions such as:

- A purchasing guide.

- A guideline for the storeroom.

- A work schedule for the food service.

- The product list and price schedule.

- The primary means of advertising food, beverage and service.

On the other hand, Qamiha, (2020); and Foskett, Ceserani, and Kinton, (2008) pointed that when planning the menu should be considering the following: Qamiha

- Type and size of establishment: pub, school, hospital, restaurant ...etc.

- Customer profile.

- Special requirements: Muslim (Halal), Kosher, Vegetarian ...etc.

- Time of the year: certain dishes acceptable in summer may not be so in winter.

- Foods in season.

- Special days.

- Time of day.

- Price range.

- Number of course.

- Sequence of course.

- Use menu language that customers understand.

- Sensible nutritional balance.

- No unnecessary repetition of ingredients from dish to dish.

- No unnecessary repetition of flavors and colors.

\section{METHODOLOGY}

This part of the study includes limitations and study samples, as well as review of the tools that used in this study, which are as follows:

1. Personal interviews with those responsible for planning food menus

2. Personal observation checklist.

\section{Limitations}

The present study aims to measure the awareness and knowledge of who are responsible for planning the food menus in the Egyptian resorts of the study samples regarding to the food menu procedures and the actual application of these procedures. Indubitably; it was too difficult to sample all resorts, because it is prohibitive in terms and conditions of cost, time and accessibility. Therefore, this study was limited to four and five-star hotels resorts in the areas of Sharm El Sheikh and Hurghada. It selected these areas because of variety of reasons, for example; those areas have the largest share of the volume of tourism coming to Egypt, in addition to the availability of a large number of resorts, which facilitates the search process.

\section{The Study Samples}

The resort samples of this study were selected randomly. According to the Egyptian Hotel Association (2016), and Free Hotel Guide.com (2015) there are 106 four and 
five star resorts in Sharm El Sheikh. But, there are 73 four and five star resorts in Hurghada. This has been use of 10 resorts of Sharm El Sheikh representing 9.4\% of the total number of four and five star resorts. As well as 7 resorts of Hurghada represents $9.4 \%$ of the total number of four and five star resorts. The following table (1) shows the list of investigated resorts.

\section{Table 1}

A summary of the research samples

\begin{tabular}{|c|c|c|c|c|}
\hline No. & $\begin{array}{l}\text { Investigated } \\
\text { destinations }\end{array}$ & No. & $\begin{array}{c}\text { Investigated } \\
\text { Resorts }\end{array}$ & Category \\
\hline \multirow[t]{10}{*}{1.} & \multirow{10}{*}{$\begin{array}{l}\text { Sharm El } \\
\text { Sheikh } \\
\text { Destination }\end{array}$} & 1. & C.S.H.V. & 4 Star \\
\hline & & 2. & E.H.S.H. & $4 \mathrm{Star}$ \\
\hline & & 3. & M.L.R. & $4 \mathrm{Star}$ \\
\hline & & 4. & R.B.R.S. & 4 Star \\
\hline & & 5. & O.R. & $5 \mathrm{Star}$ \\
\hline & & 6. & P.S.E.S. & $5 \mathrm{Star}$ \\
\hline & & 7. & R.G.A. & $5 \mathrm{Star}$ \\
\hline & & 8. & R.R. & $5 \mathrm{Star}$ \\
\hline & & 9. & SS.E.S.R. & $5 \mathrm{Star}$ \\
\hline & & 10. & S.R.S.I.V. & $5 \mathrm{Star}$ \\
\hline \multirow[t]{7}{*}{2.} & \multirow{7}{*}{$\begin{array}{l}\text { Hurghada } \\
\text { Destination }\end{array}$} & 1. & A.B.A.V.H. & 4 Star \\
\hline & & 2. & B.A.H. & $4 \mathrm{Star}$ \\
\hline & & 3. & S.I.M.R. & $4 \mathrm{Star}$ \\
\hline & & 4. & R.A.R. & 4 Star \\
\hline & & 5. & S.H.R. & $5 \mathrm{Star}$ \\
\hline & & 6. & H.M.B.R. & $5 \mathrm{Star}$ \\
\hline & & 7. & T.B.S.A.P. & $5 \mathrm{Star}$ \\
\hline
\end{tabular}

Note: The investigated hotel sample names were used by coding methods

\section{Research Tools}

\section{1) Personal interviews}

Personal interviews were one of the main sources of evidence which represents one of the key aspects of this study. A thirty-four food and beverage managers; chefs and their assistants (two of those responsible at each resort) were investigated in seventeen resorts in Sharm El Sheikh and Hurghada destinations (see Table 1). The overall purpose of these personal interviews is to identify the extent of their awareness and knowledge regarding the food menu procedures that actually applied.

\section{2) Personal observation checklist}

An observation checklist was used to ensure that procedures were correctly applied. The checklist was conducted on 17 four and five star resorts as indicated earlier. The observation checklist form was developed based on the relevant review of literature and then approved by six experts in the hospitality industry's field. Three of the experts were academic, while the others four were hospitality industry's managers. The list has been divided into the following sections:

1. Food Menus. 
2. Food Menus and Kitchen.

3. Food Menus and Restaurant.

The form included 33 questions and was evaluated through the following scale:

- Three points for a good level.

- Two points for the average level.

- One point for the poor level.

- Zero for the missing categories.

\section{RESULTS AND DISCUSSION}

1) The analysis of personal interviews

As indicated earlier, the aim of the interview is to identify the extent of their awareness and knowledge regarding the food menu procedures that actually applied. The following paragraphs explain this issue in all the investigated resorts.

Question 1: Familiarity with the concept of the menu

This question was designed to highlight if the respondents in the investigated resorts are fully familiar regarding the concept of menu or not. All the interviewees mentioned that they are familiar with the concept of menu. They also agreed that the definition of the menu as: "a list of food items served by any food service operation and menus are statements of the food and beverage items provided by a food service establishment, primarily based on guest needs or demands and designed to achieve resort objectives. The menu is the production plan governing almost every phase of the resorts and becomes the backbone of a food service or hospitality operation". These findings agree with Liza, and Lientjie, (2008) and Meal Planner (2020) when they defined the menu.

Question 2: The opinions about the importance of the menu

The aim of this question is to identify the perspectives of the interviewees at the investigated resorts in terms of the importance of the menu. All the interviewees at the investigated resorts stated that there is great importance for the menu and this importance are as follows:

- The menu represents the backbone of any hospitality industry establishments, where that is specified the required raw materials, tools and equipment, the type and number of employees ... etc.

- It is the tool by which the guests acquainted with the products, prices and determine what is appropriate for them.

- It's a tool through which explaining and interpreting the food items in an attractive way can be taken as an advantage to attract guests and increase sales.

- It can be used as a marketing and advertising tool.

- It's a method to simplify sales procedures and save time and effort that could be done by the service employees in the case to explain each item in the menu.

- It's an important way to avoid a number of risks, such as food allergy.

These findings agree with Davis, and Rensburg, (2008) and McVety, Ware, and Ware, (2008) when they explain the importance of menu.

Question 3: The type of food menus that used 
The aim of this question is to identify the type of food menus that used in the investigated resorts. All the interviewees at the investigated resorts stated that they are using many types of menus in their resorts and those types of menus are as follows:

1. A la carte menu.

2. Set menu.

3. Buffet menu.

This shows that these three types of menus are the most commonly used in the investigated resorts.

Question 4: Menu planning rules and procedures

The aim of this question was to identify the perspectives of the interviewees at the investigated resorts in terms of the rules and procedures of planning food menus. The vast majority of interviewees (98\%) were fully aware of the rules and procedures that should be taken into account when planning food menus. In contrast, $2 \%$ of them were not able to clarify a large number of those rules and procedures. It can summarize the rules and procedures agreed upon by the majority as follows:

- The possibilities of the kitchen and restaurant in terms of tools and equipment.

- The human potential in terms of type, experience, skill and number of employees.

- The availability of raw materials.

- The element cost.

- The guest type and nationality.

- The availability and quality of store spaces.

- The consistency of colors.

- The simplicity of the language that used when writing the menus.

- Menu should be balanced in terms of value of health, nutritional, coordination, diversity of cooking methods, ingredients and ...etc.

These findings agree with Patch, (2020); Sprenger, (2015); Davis, and Rensburg, (2008); and Foskett, Ceserani, and Kinton, (2008) when they explained the rules and procedures that should be considered when started planning the menus.

Question 5: The most important consideration when planning the menu

This question was designed to determine the most important consideration when planning the menu. All the interviewees at the investigated resort are agreed that the most important rules and procedures that should be taken into account when planning the menus were in the following:

- The guest type and nationality.

- The possibilities of the kitchen and restaurant in terms of tools and equipment.

- The human potential in terms of type, experience, skill and number of employees.

Question 6: The external and internal factors that lead to change menus

The aim of this question was to identify the perspectives of the interviewees at the investigated resorts in terms of the external and internal factors that lead to change menus. There were $75 \%$ of the interviewees in the investigated resorts declared that there were many internal and external factors which could represent a major reason for the change menus and the most important of these factors included: 
- Market price disruptions.

- Equipment and utensils maintenance problems.

- Increasing the employee's turnover.

- Changing the type of guests.

- Guest's complaints.

- Changing the kitchen staff or manager.

- Development and renewal in the kitchen or restaurant.

While $25 \%$ of the interviewees in the investigated resorts stated that there was no specific reason can contribute to change the menu, only if there was a disadvantage in the planning that menu.

Question 7: The procedures that considered when renewing/changing menu This question was designed to determine the most important procedures that considered when renewing/changing the menu in order to ensure that the expectations of guests. The vast majority of interviewees (98\%) highlighted that there were many procedures should be followed when starting to renew or change the menu, and the most important procedures that were agreed as follows:

- Survey of guest opinions.

- Review guest complaints forms.

While $2 \%$ of the interviewees in the investigated resorts mentioned that was changing menus periodically in order to achieve renewal, modernization and avoid boredom guest's occurrence of no more. Therefore, the resort managers must take into account interest in solving this matter.

Question 8: The menu trends

The aim of this question was to identify the perspectives of the interviewees at the investigated resorts in terms of the menu trends. There were $55 \%$ of the interviewees in the investigated resorts did not specify any new for the menu trends, while $45 \%$ of the interviewees confirmed that there was always a new about food menus specially in terms of food items, there was interested in healthy food and organic food in addition to writing the number of calories per meal. There is also a new trend in the design and selection of forms, and there are a number of restaurants using electronic menus that can be designed on the touch screen or iPod and so on. Therefore, resort managers must take into account interest in increasing awareness of new trends, especially in terms of menus.

Question 9: The importance of description of menu items

This question was designed to determine the important of description of menu items. There were $85 \%$ of the interviewees in the investigated resorts stated that explaining and interpreting menu items had great importance since it contributes to facilitate the process of selecting the food items desired by the guests as it may help the guests to understanding the menu items correctly, also to avoid problems that related to lack of the guests clearly understanding the food menu items in addition to the control the food allergy hazards. While $15 \%$ of the interviewees cannot explain the significance 
and interpretation of existing varieties and mentioned that this role should be played by the service staff.

Question 10: Knowing the messages they send to guests through the food menus This question was designed to determine the message they want to deliver to the guests by using the food menus. All of the interviewees were agreed that the message they want to be connected to the guests through the planning food menu can be represented as follows:

- To highlight the quality and importance of the establishment.

- To highlight the true value of service that provided.

- The application of the hotel tradition in service and catering.

- Make it easier for guests and help them in the process of selecting food items.

- Attracting the attention of guests and to creating help a kind of suspense in order to increase sales.

Question 11: Knowing and identifying the methods and tools that used to make sure the arrival of messages required to be delivered through the food menus to the guests The aim of this question was to identify the perspectives of the interviewees at the investigated resorts in terms of the methods and tools that used to make sure the arrival of messages required to be delivered through the food menus to the guests. The results showed that there were about $95 \%$ of the interviewees in the investigated resorts declared that there were several methods and tools that used to make sure the arrival of messages required to be delivered through the food menus to the guests, these methods and tools can be summarized in the following points:

- Survey the opinions of guests through special forms or the guest comment cards.

- Survey the opinions of guests directly through restaurant managers or service staffs during and after a meal.

- Review of regular guests by phone or E-mail.

- Review of the comments that posted on the Trip Advisor pages.

- Review sales reports and others analysis sheets.

While there were $5 \%$ of the interviewees in the investigated resorts highlighted that they could make sure that the message arrives just only by follow the guests during the meal and make sure there are no complaints about this matter.

Question 12: Suggestions or recommendations

This question aimed to identify the respondents' suggestions or recommendations concerning the study subject. Most of the respondents in the investigated resorts mentioned that there were some suggestions or recommendations, and it could be summarized as follows:

- Providing specialized training courses relating to planning food menus.

- Supporting and developing the food and health awareness.

- Providing create staff who are trained, informed and knowledgeable assets of nutrition, culinary arts and safety so that can improve the level of planning menus. 
- Opportunities must be provided to employees by providing creative suggestions in the field of planning food menus.

\section{2) The analysis of personal observation checklist}

Table 5 showed the findings of personal observation checklist, all attributes were evaluated as following: First section: Food menus (which included 15 questions $* 3$ maximum points for each question $=45$ points), Second Section: Food menus and kitchen (which included 10 questions $* 3$ maximum points for each question $=30$ points) and Third Section: Food menus and restaurant (which included 8 questions * 3 maximum points for each question $=24$ points). The observation checklist was divided into three main sections:

\section{Section one: Food menus}

This section comprised the following fifteen questions:

1. Is written Menus being available even for items displayed in the buffets?

2. Are the food menus written in in several languages?

3. Is the way of writing the food menu easy and clear meanings and are described in terms of ingredients?

4. Is the font size used in the writing of the menu is clear and suitable for easy reading?

5. Are there any signs or signals illustrate items containing components show a food allergy?

6. Is there not clear on terminology used?

7. Is taking into account the traditional way to sequence items menu?

8. Is the menu provided a clean and fitly?

9. Is there variety in items and raw materials used?

10. Is taking into account the availability and diversity of the nutritional value of the elements?

11. Is there a good variety items and is available for children or vegetarians?

12. Is there a repeat in the list?

13. Is the menu suitable with the nature and quality of the nationality of and guests?

14. Is there variety in the use of different methods of cooking?

15. Is to take advantage of recent trends in the field of foods, such as organic food service ...etc.?

\section{Section tow: Food menus and kitchen}

This section comprised the following ten questions:

1. Are taking into account the Human Potential of kitchen in terms of kitchen staffs number and experience? 
2. Are the kitchen staffs have familiar and awareness with food menus items, components and how to production?

3. Is allocated for food dry storage space sufficient and appropriate matching proper health requirements?

4. Is allocated for food refrigerator storage space sufficient and appropriate matching proper health requirements?

5. Is allocated for food freezer storage space sufficient and appropriate matching proper health requirements?

6. Are taking into account the Human Potential of kitchen in terms of kitchen staffs number and experience?

7. Are the kitchen staffs have familiar and awareness with food menus items, components and how to production?

8. Is allocated for food dry storage space sufficient and appropriate matching proper health requirements?

9. Is allocated for food refrigerator storage space sufficient and appropriate matching proper health requirements?

10. Is allocated for food freezer storage space sufficient and appropriate matching proper health requirements?

\section{Section three: Food menus and restaurant}

This section comprised the following eight questions:

1. Are taking into account the physical a possibility of the restaurant in terms of tools, equipment and all of that is required to serve food menu items?

2. Are taking into account the human potential of restaurant in terms of service staffs number and experience?

3. Are the service staffs familiar and awareness with food menus items, components and how to production?

4. Is there any change or lacked of one of ingredients of the food varieties that provided from the traditional way of submission?

5. Are there any food menu items are not available?

6. Is there value of satiation available in the food menu items that offered?

7. Are taking into account symmetry the colors in the food items that provided?

8. Is the food menu that used appropriate and consistent with the overall atmosphere of the restaurant or hotel?

Food menus

Food menus and kitchen

Food menus and restaurant 


\section{Table 5}

Findings of personal observation checklist

\begin{tabular}{|c|c|c|c|c|c|c|c|}
\hline \multirow{3}{*}{$\begin{array}{l}\text { Investigated } \\
\text { destinations }\end{array}$} & \multirow{3}{*}{\multicolumn{2}{|c|}{ Resorts/Score }} & \multicolumn{3}{|c|}{ Attributes } & \multirow[b]{2}{*}{ Total } & \multirow{3}{*}{ Ranks } \\
\hline & & & \multirow{2}{*}{$\begin{array}{c}\begin{array}{c}\text { Food } \\
\text { Menus }\end{array} \\
45 \\
\end{array}$} & \multirow{2}{*}{$\begin{array}{c}\text { Food } \\
\text { Menus \& } \\
\text { Kitchen }\end{array}$} & \multirow{2}{*}{$\begin{array}{c}\begin{array}{c}\text { Food } \\
\text { Menus \& } \\
\text { Restaurant }\end{array} \\
24 \\
\end{array}$} & & \\
\hline & & & & & & 99 & \\
\hline \multirow{20}{*}{$\begin{array}{l}\text { Sharm El } \\
\text { Sheikh } \\
\text { Destination }\end{array}$} & \multirow[t]{2}{*}{ C.S.H.V } & $\begin{array}{c}\text { Actual } \\
\text { score }\end{array}$ & 36 & 22 & 20 & 78 & \multirow[t]{2}{*}{6} \\
\hline & & $\%$ & 80 & $\begin{array}{l}73.3 \\
\end{array}$ & 83.3 & 78.8 & \\
\hline & \multirow[t]{2}{*}{ H.S.H } & $\begin{array}{l}\text { Actual } \\
\text { score }\end{array}$ & 22 & 16 & 14 & 52 & \multirow[t]{2}{*}{17} \\
\hline & & $\%$ & 48.9 & 53.3 & 58.3 & 52.6 & \\
\hline & \multirow{2}{*}{ M.L.R } & $\begin{array}{c}\text { Actual } \\
\text { score }\end{array}$ & 37 & 25 & 18 & 80 & \multirow[t]{2}{*}{5} \\
\hline & & $\%$ & 82.2 & 83.3 & 75 & 80.8 & \\
\hline & \multirow[t]{2}{*}{ R.B.R.S } & $\begin{array}{l}\text { Actual } \\
\text { score }\end{array}$ & 33 & 22 & 17 & 72 & \multirow[t]{2}{*}{7} \\
\hline & & $\%$ & 73.3 & 73.3 & 70.8 & 72.7 & \\
\hline & \multirow[t]{2}{*}{ O.R } & $\begin{array}{l}\text { Actual } \\
\text { score }\end{array}$ & 30 & 20 & 15 & 65 & \multirow[t]{2}{*}{10} \\
\hline & & $\%$ & 66.7 & 66.7 & 62.5 & 65.7 & \\
\hline & \multirow[t]{2}{*}{ P.S.E.S } & $\begin{array}{c}\text { Actual } \\
\text { score }\end{array}$ & 25 & 16 & 15 & 56 & \multirow[t]{2}{*}{14} \\
\hline & & $\%$ & 55.6 & 53.3 & 62.5 & 56.6 & \\
\hline & \multirow[t]{2}{*}{ R.G.A } & $\begin{array}{l}\text { Actual } \\
\text { score }\end{array}$ & 38 & 25 & 18 & 81 & \multirow{2}{*}{4} \\
\hline & & $\%$ & 84.4 & 83.3 & 75 & 81.8 & \\
\hline & \multirow[t]{2}{*}{ R.R } & $\begin{array}{l}\text { Actual } \\
\text { score }\end{array}$ & 22 & 18 & 15 & 55 & \multirow[t]{2}{*}{16} \\
\hline & & $\%$ & 48.9 & 60 & 62.5 & 55.6 & \\
\hline & \multirow[t]{2}{*}{ S.S.E.R } & $\begin{array}{l}\text { Actual } \\
\text { score }\end{array}$ & 40 & 28 & 20 & 88 & \multirow[t]{2}{*}{2} \\
\hline & & $\%$ & 88.9 & 93.3 & 83.3 & 88.9 & \\
\hline & \multirow[t]{2}{*}{ S.R.S.I.V } & $\begin{array}{c}\text { Actual } \\
\text { score }\end{array}$ & 35 & 17 & 17 & 69 & \multirow[t]{2}{*}{9} \\
\hline & & $\%$ & 77.8 & 56.7 & 70.8 & 69.7 & \\
\hline \multirow[t]{2}{*}{$\begin{array}{c}\text { Hurghada } \\
\text { Destination }\end{array}$} & \multirow{2}{*}{$\begin{array}{l}\text { A.B.A.V. } \\
\text { H }\end{array}$} & $\begin{array}{c}\text { Actual } \\
\text { score }\end{array}$ & 28 & 20 & 16 & 64 & \multirow[t]{2}{*}{11} \\
\hline & & $\%$ & 62.2 & 66.7 & 66.7 & 64.7 & \\
\hline
\end{tabular}




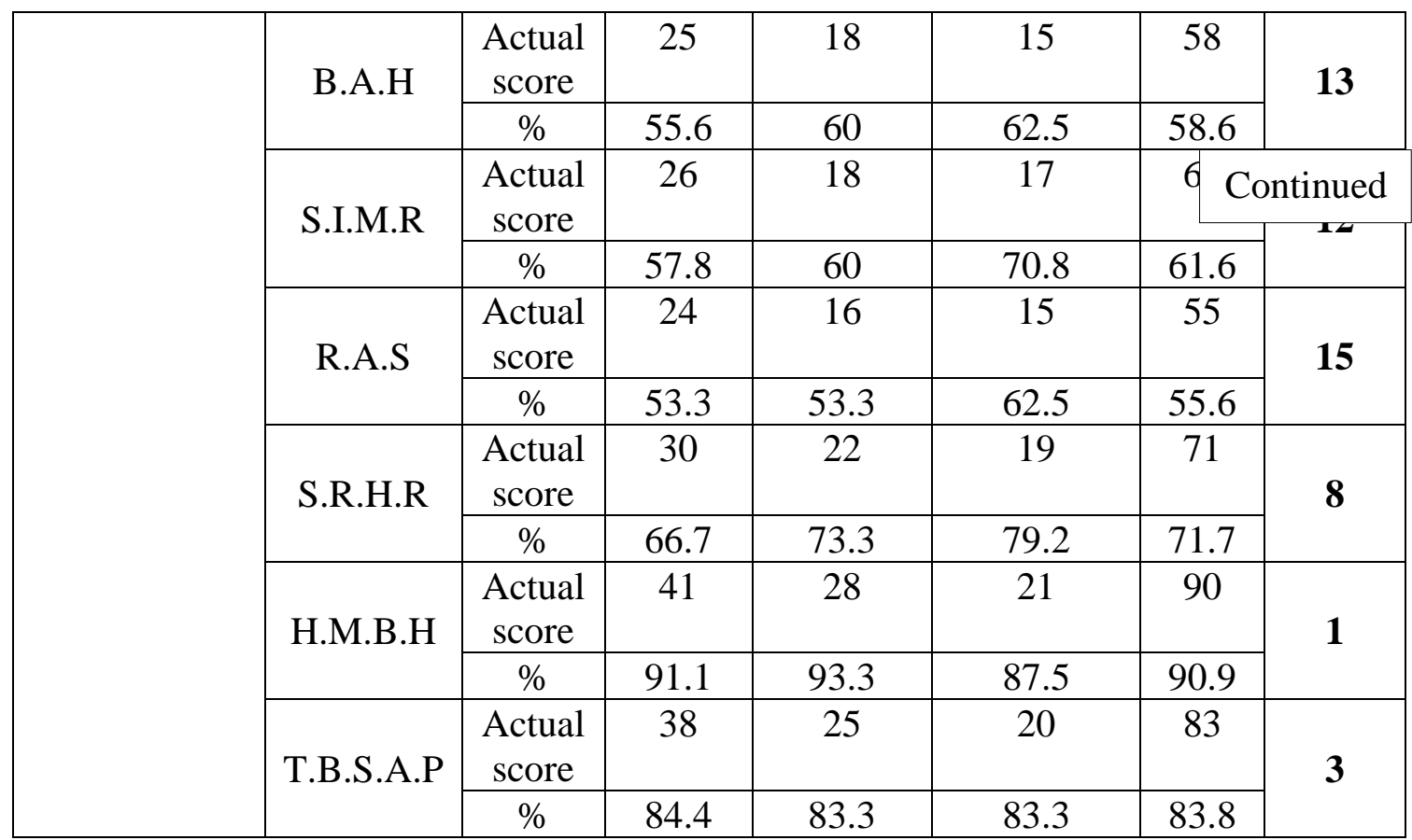

Notes: 1) Number one is the highest in the ranking

\section{2) The investigated hotel sample names were used by coding methods}

The illustrated data in Table 5 show that the investigated resorts were arranged as follows: (1) H.M.B.H achieved the maximum points by scoring 90 points $(90.9 \%)$; followed by (2) S.S.E.R by scoring 88 points (88.9\%); (3) T.B.S.A.P by scoring 83 points (83.8\%); (4) R.G.A by scoring 81 points (81.8\%); (5) M.L.R by scoring 80 points (80.8\%); (6) C.S.H.V by scoring 78 points (78.8\%); (7) R.B.R.S by scoring 72 points $(72.7 \%)$; (8) S.R.H.R by scoring 71 points $(71.7 \%)$; (9) S.R.S.I.V by scoring 69 points (69.7\%); (10) O.R by scoring 65 points (65.7\%); (11) A.B.A.V.H by scoring 64 points $(64.7 \%)$; (12) S.I.M.R by scoring 61 points $(61.6 \%)$; (13) B.A.H by scoring 58 points (58.6\%); (14) P.S.E.S by scoring 56 points (56.6\%). Meanwhile, both achieved (15) R.A.S. and (16) R.R the same score 55 points (55.6\%); finally came out (17) H.S.H by scoring 52 points $(52.6 \%)$. All of the previously mentioned scores were out of 99 point.

\section{CONCLUSION}

The results concluded from the analysis of the personal interviews and the observation checklist could be summed in a gap between the theoretical knowledge of the procedures of planning food menus and the actual practice in the Egyptian resorts of these rules, and this could be due to the following:

1- A large percentage of those responsible for planning food menus in the research sample resorts informed and aware of the rules and procedures of planning food menus in theory only. While, not practicing that knowledge significantly in practice due to many reasons, which include the following:

- The unavailability of some kitchen or restaurant tools and equipment.

- Maintenance problems that related with equipment and workplaces. 
- The lack of adequate number of employees.

- Increase in the employee's turnover rates.

- Work stress due to increased occupancy rates in the resorts.

2- The All-inclusive system in the resorts contributed to the weakness of the employee's skill and lack of experience as a result of the daily repetition of menus.

3- The cost element and resort owners and manager's pressures become a source of concern and pressures on those responsible for planning menus in the inability to apply some rules and procedures related to the quality of planning menus.

4- They should pay attention in the design and organization of menus and a good selection of colors.

5- Weak level of interest in food menus, especially with regard to shape, use of colors, design, and use of images.

6- Low level of adherence to general and basic rules in planning menus, especially with regard to each of the following:

- Failure to write an explanation explaining the items on the food menu.

- Attention should be paid to the linguistic revision of what is written in the menus.

- Should pay attention to write the menu items in more than one language.

- Should be work to meet the guest's desires and expectations during the planning food menus.

\section{RECOMMENDATIONS}

Based on the results of the study, the following recommendations could be suggested:

\section{First: Resorts Recommendations:}

1) Resorts should increase the awareness and skills of employees especially those responsible for planning food menus through support training programs.

2) Resorts should provide training programs to support employees especially those responsible for planning menus ideas, developments and new trends in this filed.

3) Resorts should be ensuring a good application of the rules and procedures that relating to planning menus.

4) Resorts should be ensuring writing menus with more than one language, preferably Arabic, English and then the guests mother language in order to achieve quality and avoid the risks for example food allergy.

5) Resorts should be ensuring diversity of sales methods and do not depend on only the All-inclusive system until they restored work experience and raise the level of performance of employees, especially with regard to the planning menus.

6) Resorts should work to improve the level of price so that they can provide the best quality and diversity of products and meet the guest expectations. 
7) Resorts should work to improve the quality and maintenance level of equipment and keep up of development in this field.

8) Resorts should also work to reduce the level of employees turnover and increase the number of employees to the extent appropriate.

\section{Second: General Recommendations:}

1) Hotel education institutions should pay attention to providing specialized training programs in the field of planning menus

2) Governmental institutions should be developing an evaluation of the food menus can help to ascertain the quality of menu planning

\section{REFERENCES}

\section{First: English References}

- Al-Juboori, N., and Al Saleem, A., (2012). "Analysis of the Menus' Factors that are Influential in Increasing the Volume of Sales: An Empirical Study on First-Class Restaurants in Baghdad". European Scientific Journal, December Edition Vol. 8, No. 28, ISSN: 1857-7881, (Print) e-ISSN: 185-7431. Pp. 46-60.

- Anupam, M. (2006). "Food and Beverage Management", Published in India by Isha Books. Pp. 55-62.

- Barbara, G; and Sandi, S. (2005). "Beating the High Cost of Eating: The Essential Guide to Supermarket Survival".

- Barker, CH., Cavaliere, J., Fitzpatrick, M., Leaver, M., Mayerson, D., Rosen, M., Thompson, K., and Whittington, L. (2013). Best Practices for Nutrition, Food Service and Dining in Long Term Care Homes: Revised Working Paper. Ontario Long Term Care Action Group Dietitians of Canada, Pp, 10-12. Website, www.dietitians.ca.

- Bernard, D. Andrew, L. Ioannis, P. and Peter, A. (2012). "Food and Beverage Management", Library of Congress Cataloging.

- Brakes, S. (2013). Available from: http://www.brake.co.uk/menusandevents/ menuplanning/prici-your-menu", [Accessed on 22-09-2014].

- Cathie, R. (2010). Safety, Nutrition and Health in Early Education, $4^{\text {th }}$ Edation., Pp. 354.

- Cichy, R. (2004). "Food Safety Managing the HACCP Process". Educational Institute of the American Hotel and Lodging Association, USA., Pp. 5 - 18.

- Corcoran, V. and Bloomquist, D., (2001). Study Unit: Menu Planning. Harcourt Learning Direct Publications, Inc. USA. Pp. 1-35.

- Davis, L., and Rensburg, L., (2008). "The Hospitality Industry Handbook on Nutrition and Menu Planning: For South African Students and Practitioners". Juta \& Co. Pp. 236.

- Divine, C. (2013). Available from: "http://www.divinecaroline.com/life-etc/homefood/cost-effective-menu-planning", [Accessed on 11-09-2014].

- Egyptian Hotel Association (EHA), (2016). The Egyptian Hotel Guide. 34 ${ }^{\text {th }}$ Edition 2015 - 2016, Cairo, Egypt. 
- Foskett, D., Ceserani, V., and Kinton, R., (2008). "The Theory of Catering". 10 ${ }^{\text {th }}$ Ed. British Meat. Hodder and Stoughton a member of the Hodder Headline Group. Pp. 316-325.

- Free Hotel Guide.com. (2015). Available from: http://www.egypt.freehotel guide.com/. Egypt Hotels Information Guide. [Accessed on03-11-2016].

- Graham, D; Michel, P; and David, O. (2012). "Cookery for the Hospitality Industry", $6^{\text {th }}$ Edition.

- Kohinoor, S. (2010). Available from: "http://www.slideshare.net/bhavinsp/ menuplanning-costing-engineering", [Accessed on16-10-2014].

- Lendal, H; and Diane, W. (2008). "Management by Menu Study Guide". $4^{\text {th }}$ Ed., John Wiley and Sons, Inc., Hoboken, New Jersey.

- Lenore Publication. (2020). "Weekly Meal Planner: 52 Weeks of Menu Planning Pages with Weekly Grocery Shopping List Christmas New Year Funny Gift for Women Cute Foods Pattern". Independently Published. ISBN: 9798553098421.

- Liza, G; and Lientjie, V. (2008). "The Hospitality Industry Handbook on Nutrition \& Menu planning", p.235.

- Meal Planner. (2020). "Weekly Meal Planner: Menu Planning and Shopping List". Independently Published. ISBN: 1658673824, 9781658673822

- Miller, J.; Dopson, L.; and Hayes, D. (2006). "Food and beverage cost control". $4^{\text {th }}$ Edition, New Jersey, John Wiley \& Sons, Inc., Pp. 484-494.

- Oxenreider, T., (2013). "A Basic Guide to Menu Planning", Available from: "http://simplemom.net/ how-to-menu-plan/", [Accessed on 12-09-2013].

- Patch, G. (2020). "Smart \& Easy Meal Planning". Rowman \& Littlefield. SIBN: 1620933586, 9781620933589. Pp. 43: 50

- Peter, R; Michael, L; and Stephen, L. (2013). "Tourism”, page 181. 38 Chauncey Street, Suite 1002, Boston, MA 02111 USA.

- Spears, M., and Gregoire, M., (2004). "Foodservice Organizations: A Managerial and Systems Approach". $5^{\text {th }}$ Ed. Pearson Education, Ltd. USA. Pp. 45, 46.

- Sprenger, R., (2015). "Supervising Food Safety (Level 3)". A text for Level 3 Food Safety courses and a reference for supervisors. 16th Edition. Highfield. Co. Uk Limited. UK. Pp. 28, 90, 152, 153.

\section{Second: Arabic References}

$$
\begin{aligned}
& \text { - الإتحاد المصري للغرف السياحية (ETF) و AH\&LA، (2019)، "تتمية مهارات الأغذية والمشروبات"، }
\end{aligned}
$$

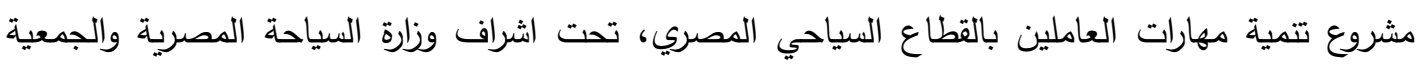

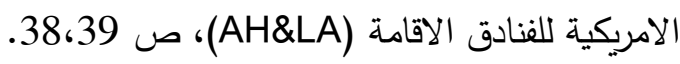

$$
\begin{aligned}
& \text { - الإتحاد المصري للغرف السياحية (ETF) و AH\&LA)، (AH\&A)، (2010)، "إدارة الأغذية والمشروبات"، مشروع تتمية } \\
& \text { مهارات العاملين بالقطاع السياحي الصصري، تحت اشراف وزارة السياحة الدصرية والجمعية الامريكية للفنادق }
\end{aligned}
$$

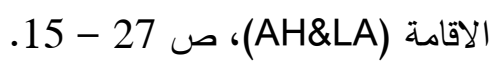

$$
\begin{aligned}
& \text { - - وليد أمين نافع قميحة، (2020). "إدارة الطعام والثراب: الثنامل في إدارة الطعام والثراب". دار اليازوري }
\end{aligned}
$$

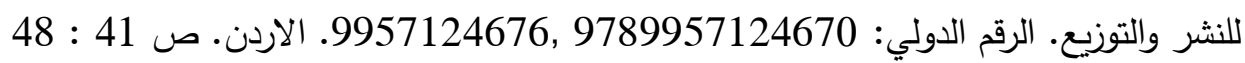




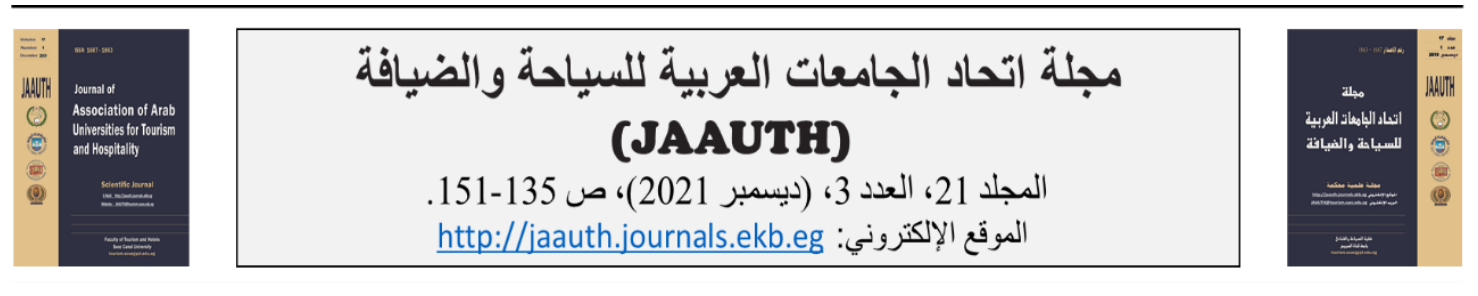

إجراءات تخطيط قوائم الطعام بين المعرفة والممارسة الفعلية في المنتجعات المصرية مصطفي عطية عبد الفتاح

كلية السياحة والفنادق، جامعة بني سويف عبد لفئ

معلومات المقالة المقاحة

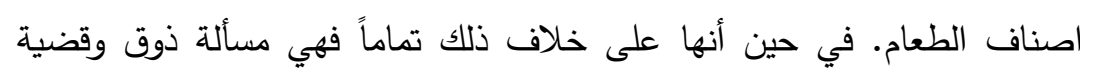
علمية وفنية في كيفية اختيار اصناف الطعام كما انها تتكون من مجموعة كبيرة

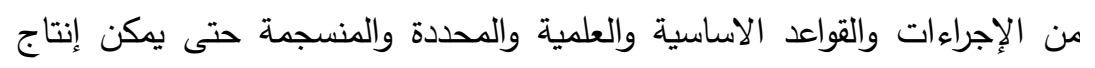
قوائم الطعام؛ تخطيط

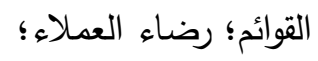
انواع القوائم. قائمة هميزة وناجحة تلبي توقعات الضيوف. حيث أن قوائم الطعام التي تعد إعداداً

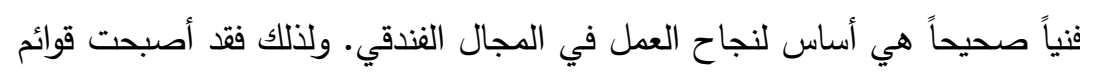

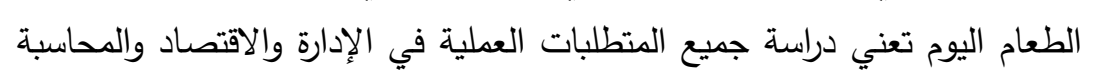

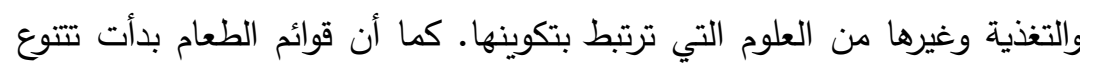

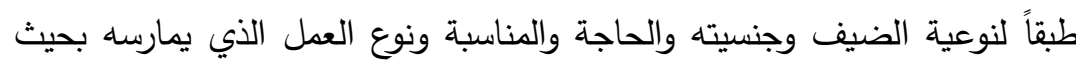

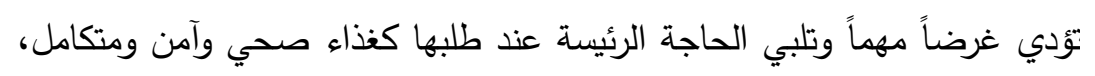

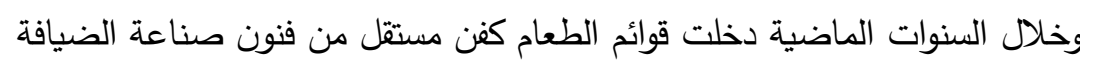
ووضع لها متخصصون قواعد وأساليب متتوعة وذلك نتيجة للدراسات الميدانية

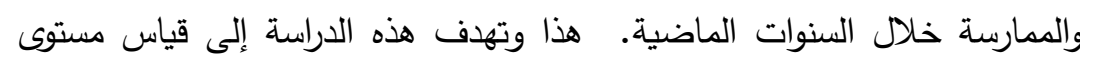

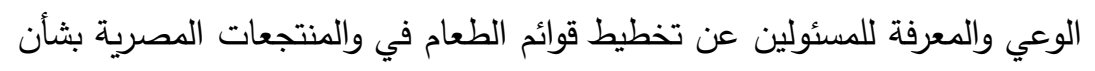

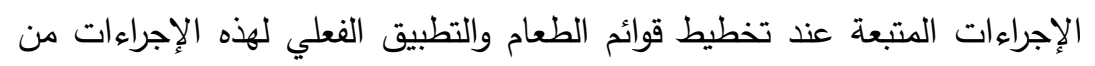

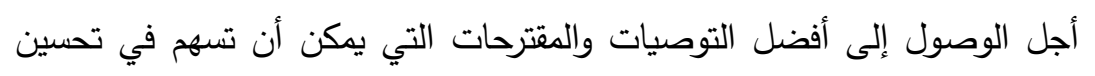

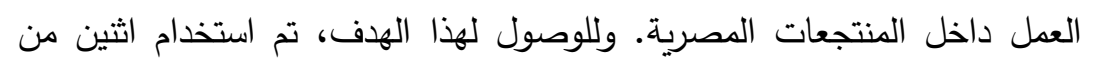

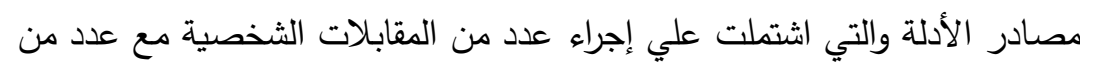

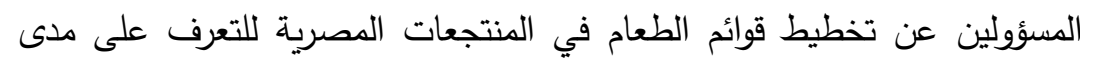

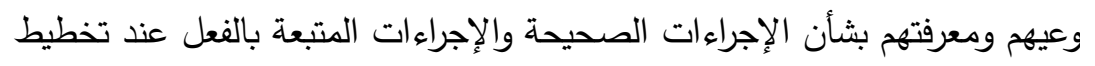

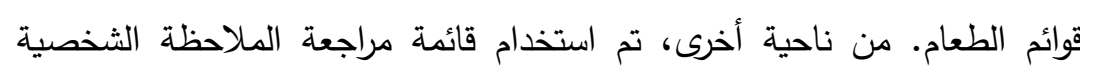

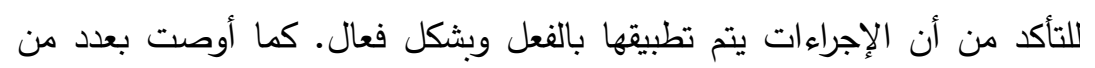

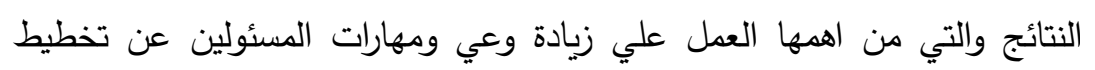
قوائم الطعام من خلال برامج التدريب المساندة. 